\title{
KEBIJAKAN DAN STRATEGI PENGELOLAAN MANAJEMEN MODAL KERJA
}

\author{
Christian Herdinata \\ Program Studi International Business Management \\ Universitas Ciputra Surabaya \\ UC Town, CitraLand, Surabaya 60219 \\ Cliff Kohardinata \\ Program Studi International Business Management \\ Universitas Ciputra Surabaya \\ UC Town, CitraLand, Surabaya 60219 \\ Meidiahna Kusuma \\ Program Studi International Business Management \\ Universitas Ciputra Surabaya \\ UC Town, CitraLand, Surabaya 60219
}

\begin{abstract}
ABSTRAK
Modal kerja (working capital) yaitu kas, piutang, persediaan. Perusahaan mengikuti suatu siklus modal kerja. Bererapa hal yang terkait dengan hal tersebut yaitu: (1) konversi kas (cash conversion cycle) merupakan berapa waktu dana terikat dalam modal kerja atau berapa lama waktu antara pembayaran untuk modal kerja dan penagihan kas dari penjualan modal kerja tersebut (Brigham dan Houston, 2014); (2) periode konversi persediaan (average collection period) merupakan rata-rata waktu yang dibutuhkan untuk mengubah bahan mentah menjadi barang jadi dan menjualnya (Brigham dan Houston, 2014); (3) periode penerimaan rata-rata (average collection period) yaitu rata-rata waktu yang dibutuhkan untuk mengubah piutang perusahaan menjadi kas atau untuk menagih kas setelah terjadi penjualan; (4) periode penangguhan utang (payables deferral period) yaitu rata-rata waktu antara pembelian bahan baku dan tenaga kerja dengan pembauran kasnya. Hasil penelitian ini menjelaskan tentang strategi dan kebijakan yang dapat digunakan pada usaha skala menengah.
\end{abstract}

\section{ABSTRACT}

Working capital (capital) ie cash, accounts receivable, inventory. Companies follow a working capital cycle. Some things related to this are: (1) the cash conversion cycle is how much time the funds are tied up in working capital or how much time between the payment for working capital and cash collection from the sale of working capital (Brigham and Houston, 2014 ); (2) the average collection period is the average time required to convert raw materials into finished goods and sell them (Brigham and Houston, 2014); (3) the average collection period is 
the average time required to change a company's receivables into cash or to collect cash after a sale; (4) the payable period (payables deferral period) is the average time between the purchase of raw materials and labor with cash payments. The results of this study explain the strategies and policies that can be used in medium-sized businesses.

Keywords: cash, accounts receivable, inventory, policy, strategy.

\section{PENDAHULUAN}

Modal kerja (working capital) secara sederhana mengacu pada aset lancar yang digunakan dalam operasi yaitu kas, piutang, persediaan. Seluruh perusahaan mengikuti suatu siklus modal kerja yaitu perusahaan tersebut membeli atau memproduksi persediaan, memilikinya selama beberapa waktu, dan pada akhirnya menjual serta menerima kas. Bererapa hal yang terkait dengan hal tersebut yaitu: (1) konversi kas (cash conversion cycle) merupakan berapa waktu dana terikat dalam modal kerja atau berapa lama waktu antara pembayaran untuk modal kerja dan penagihan kas dari penjualan modal kerja tersebut (Brigham dan Houston, 2014); (2) periode konversi persediaan (average collection period) merupakan rata-rata waktu yang dibutuhkan untuk mengubah bahan mentah menjadi barang jadi dan menjualnya (Brigham dan Houston, 2014); (3) periode penerimaan ratarata (average collection period) yaitu rata-rata waktu yang dibutuhkan untuk mengubah piutang perusahaan menjadi kas atau untuk menagih kas setelah terjadi penjualan; (4) periode penangguhan utang (payables deferral period) yaitu rata-rata waktu antara pembelian bahan baku dan tenaga kerja dengan pembauran kasnya.

Industri menengah memiliki potensi yang besar dalam menggerakkan ekonomi baik dalam hal output maupun penyerapan tenaga kerja. Pendapat umum menyatakan bahwa usaha besar perlu mendapatkan perhatian penuh, karena industri besar adalah motor utama penggerak pembangunan ekonomi. Sementara itu, usaha kecil dan rumah tangga juga perlu mendapat perhatian penuh karena alasan menyerap tenaga kerja dalam jumlah besar sebagai basis perekonomian rakyat dan sebagainya. Akibatnya, perhatian terhadap usaha menengah secara khusus menjadi kurang. Hal ini kemungkinan terjadi, karena industri menengah telah mampu untuk berkembang sendiri tanpa memerlukan berbagai bantuan dan proteksi. Oleh karena itu, dalam kondisi demikian perlu adanya perhatian khusus. Penelitian ini bertujuan yaitu (1) mengidentifikasi faktor eksternal dan faktor internal dari pengusaha skala menengah di Surabaya yang mempengaruhi dalam pengambilan keputusan pengelolaan modal kerja; (2) Mengidentifikasi faktor pendukung dan faktor penghambat yang dihadapi oleh pengusaha skala menengah di Surabaya dalam melakukan pengelolaan modal kerja. Hasil penelitian diharapkan dapat menjadi panduan bagi pengusaha skala menengah dalam pengambilan keputusan pengelolaan modal kerja dengan mempertimbangkan kebijakan dan strategi dalam pengelolaan modal kerja yang optimal. 


\section{TINJAUAN PUSTAKA}

\section{Manajemen Modal Kerja}

Martin et al. (1991) dalam Husnan (1998: 453) menyatakan bahwa motif spekulasi merupakan komponen paling kecil dari preferensi perusahaan akan likuiditas. Motif-motif transaksi dan berjaga-jaga merupakan alasan-alasan utama mengapa perusahaan memiliki kas. Kaitannya dengan modal kerja, kas dapat menunjukkan seberapa besar investasi perusahaan dalam modal kerja, sehingga dapat diketahui cukup tidaknya modal kerja dalam kas untuk mengoperasikan perusahaan sehari-hari. Dengan demikian, perubahan dalam kas akan mempengaruhi struktur modal kerja perusahaan. Hal ini senada dengan pernyataan bahwa peningkatan modal kerja adalah investasi, sehingga menyiratkan arus kas negatif; penurunan modal kerja menyiratkan arus kas positif (Brealey et al., 2007: 245).

Dari berbagai pernyataan yang telah disampaikan sebelumnya, dapat disimpulkan fungsi kas dari motif yang dimiliki perusahaan untuk memiliki kas serta kaitannya dengan pemenuhan kebutuhan perusahaan sehari-hari melalui modal kerja. Dari motif dimilikinya kas oleh perusahaan, motif spekulasi menjadi motif yang paling kecil dalam hubungannya dengan likuiditas. Hal ini ini dikarenakan motif spekulasi mengharuskan perusahaan untuk memperoleh keuntungan dari memiliki atau menginvestasikan kas, padahal apabila kas diinvestasikan ke dalam suatu investasi akan menyebabkan kas yang telah diinvestasikan tersebut tingkat likuiditasnya akan menjadi berkurang bila dibandingkan saat masih berupa kas, meskipun perusahaan dapat menerima keuntungan darinya. Likuiditas perusahaan akan terganggu. Dengan begitu, motif spekulasi menjadi agak sulit untuk diterapkan ketika perusahaan harus memiliki kemampuan likuiditas yang tinggi. Hal ini sejalan dengan teori bahwa profitabilitas (kemampuan menghasilkan laba) berbanding terbalik dengan likuiditas (Horne dan Wachowicz, 1997: 217).

Menurut Atmaja (2001: 389) kebijakan kredit terdiri empat variabel, yaitu: (a) periode kredit yaitu menaikkan periode kredit pada umumnya dapat mendongkrak penjualan, namun ada biaya perubahan bagi perusahaan, misalnya pembayaran tertunda. (b) standar kredit yaitu merujuk pada kemampuan keuangan minimal yang harus dimiliki calon penerima kredit serta jumlah kredit yang tersedia bagi masing-masing pelanggan; (c) kebijakan pengumpulan yaitu merujuk pada prosedur-prosedur yang digunakan oleh perusahaan untuk menagih piutang yang sudah jatuh tempo; (d) kebijakan diskon.

Perusahaan dapat menentukan kebijakan yang dapat membantu memperlancar efisiensi dari piutang. Dari perhitungan perputaran piutang, terdapat dua teori yang hampir sama yang digunakan oleh Horne dan Wachowicz (1997: 140) dalam menghitung perputaran piutang berikut formulanya. Sedangkan periode penagihannya: dari formula perhitungan perputaran piutang yang digunakan menurut Husnan (1998: 469) juga memberikan formula yang secara garis besar memiliki kesamaan dari formula sebelumnya, berikut formulanya: rata-rata piutang ditemukan dengan menjumlah piutang tahun pertama dan tahun ke dua kemudian dibagi dua. Sedangkan periode penagihannya: semakin banyak atau cepat perputaran piutang, maka semakin efisien pengelolaan piutang. Sema- 
kin sedikit periode penagihan dalam satu periode, maka akan semakin efisien penagihan piutang pada periode tersebut. Sebab semakin lambat pelanggan membayarkan kreditnya, maka jumlah hari penagihan lebih banyak dari syarat pembayaran jatuh tempo maksimal. Hal tersebut mengisyaratkan banyak kredit yang terlambat dibayarkan oleh pelanggan, dan pengelolaan piutang menjadi tidak efisien.

Berdasarkan fokus dalam manajemen persediaan yang telah disampaikan tentang fungsi persediaan, maka dapat disimpulkan sebagai berikut: (1) Mengelola sejumlah unit persediaan agar tidak sampai terjadi kekurangan terhadap kebutuhan perusahaan dalam hal produksi dan kebutuhan pasar dalam hal penjualan yang berujung pada profit. (2) Memastikan sejumlah persediaan tersedia pada waktu yang tepat, sehingga tidak terjadi penundaan yang terlalu lama yang akan menimbulkan biaya dan tidak terpenuhinya target waktu produksi dan penjualan pun akan ikut terpengaruh ketika permintaan naik namun persediaan belum kunjung datang. (3) Secara menyeluruh jumlah persediaan dan waktu yang tepat dalam menghasilkan atau memesan persediaan akan berpengaruh pada produktivitas, sehingga berpengaruh juga terhadap penjualan ketika persediaan tidak dapat memenuhi permintaan, memang tidak secara langsung mengalami kerugian, namun perusahaan kehilangan kesempatan menjual persediaan pada pelanggan.

\section{METODE PENELITIAN}

Penelitian ini menggunakan jenis penelitian kualitatif deskriptif. Penentuan subjek dalam penelitian ini dilakukan dengan metode purposive sampling yaitu pemilihan subjek ber- dasarkan kriteria yang telah ditetapkan peneliti (Bungin, 2008). Kriteria subjek dalam penelitian ini, antara lain: (1) pengusaha skala menengah; (2) konsultan bidang keuangan dengan kriteria memiliki pengalaman minimal lima tahun; (3) pihak praktisi di bidang manajemen yang memahami tentang manajemen modal kerja. Penelitian ini menggunakan metode triangulasi sumber untuk validitas dan reliabilitas yang dilakukan melalui pengkajian data yang berasal dari hasil wawancara kepada responden. Analisis data dalam penelitian mengacu pada Miles et al. (2014) dengan tiga teknik analisis data kualitatif, yaitu: reduksi data, penyajian data dan penarikan kesimpulan.

\section{ANALISIS DATA DAN PEMBA- HASAN}

Berikut pada Tabel 1 merupakan penjelasan tentang profil narasumber dalam penelitian ini, yaitu:

Tabel 1

Profil Narasumber

\begin{tabular}{|c|l|c|}
\hline No & \multicolumn{1}{|c|}{ Narasumber } & Kode \\
\hline 1. & $\begin{array}{l}\text { Pemilik dari PT. Dua Putri } \\
\text { Ciliwung di Banyuwangi } \\
\text { yang bergerak di bidang per- } \\
\text { tambangan batu. }\end{array}$ & RF \\
\hline 2. & $\begin{array}{l}\text { Pemilik dalam bisnis bidang } \\
\text { bahan bangunan di Surabaya } \\
\text { dengan memiliki banyak pe- } \\
\text { ngalaman di bidang kewirau- } \\
\text { sahaan dan menjadi Entrepre- } \\
\text { neur in Residence (EIR) di } \\
\text { Universitas Ciputra. }\end{array}$ & \\
\hline 3. & $\begin{array}{l}\text { Pemilik bisnis yang bergerak } \\
\text { di bidang teh, kopi, dan madu } \\
\text { yang sedang berkembang di }\end{array}$ & AWP \\
& $\begin{array}{l}\text { Surabaya dengan nama merek } \\
\text { Akar Pulung. }\end{array}$ & \\
\hline 4 & $\begin{array}{l}\text { Pemilik bisnis yang bergerak } \\
\text { dibidang makanan di Sura- } \\
\text { baya. Selain itu, merupakan } \\
\text { konsultan keuangan dan me- } \\
\text { miliki sertifikasi di bidang } \\
\text { perencanaan keuangan. }\end{array}$ & \\
\hline \multicolumn{2}{|l}{ DRM } \\
\end{tabular}




\begin{tabular}{|l|l|l|}
\hline 5 & $\begin{array}{l}\text { Praktisi dalam bidang opera- } \\
\text { sional dan produksi. Selain itu }\end{array}$ & AW \\
beliau juga sebagai dosen & \\
tetap di Universitas Ciputra & \\
Surabaya. Beliau juga sebagai & \\
Asesor LSP P1 untuk skema & \\
pengoperasian bisnis dan \\
analisis pengembangan bisnis.
\end{tabular}

Sumber: Data Diolah

\section{Manajemen Kas Untuk Pengelolaan Modal Kerja}

Manajemen kas untuk pengelolaan modal kerja memiliki peran penting karena kas memiliki tingkat likuiditas paling tinggi. Berikut ini merupakan pernyataan dari narasumber RF, AL dan AWP dalam penerapan manajemen kas pada usaha yang dimiliki sebagai berikut:

"Kas yang ada di perusahaan itu digunakan misal untuk investasi, entah itu untuk investasi alat lagi, atau investasi yang lainnya." (RF)

"Jadi kasnya diatur adalah penagihannya kita, jadi kolektor kita harus memberikan term waktu pada customer kita lebih dulu yaitu ada satu bulan maksimal dua bulan untuk mereka membayar daripada sebelum kita ditagih. Jadi agar cashflow itu lancar." (AL)

"Sejauh ini masih menjadi satu kas, jika ada butuh apa baru uangnya dikeluarkan, misalnya maintainance." (AWP)

Narasumber RF mengungkapkan bahwa kas yang terkumpul dalam perusahaan digunakan kembali untuk kegiatan investasi. Di sisi lain, narasumber AL menjelaskan bahwa kas perlu dikelola berkaitan dengan operasional untuk pemasukan bagi kas perusahaan. Hal ini menjadi penting berkaitan dengan pengaturan jangka waktu penagihan dan pembayaran yang dilakukan oleh perusahaan. Selain itu, narasumber AWP mengungkapkan bahwa kas digunakan untuk pembiayaan terkait biaya perawatan. Oleh karena itu, dapat disimpulkan bahwa kas dapat digunakan yaitu: (1) untuk kegiatan investasi; (2) untuk kegiatan operasional; (3) untuk kegiatan pembiayaan. Narasumber AW, AL, serta DRM menyatakan terkait manajemen kas dalam pengelolaan modal kerja sebagai berikut:

"Jadi semisal ketika dalam sebulan kita 1 juta, sebulan kita kepake 200 ribu ya kita masukin lagi 200 ribu biar stabil. Ini menurut saya ya pak. Kemudian jangan terlalu banyak kasnya, ini kan uang mati." $(A W)$

"Jadi sebenarnya toko kita itu memiliki tiga tabungan. Yang pertama itu tabungan istilah kita itu tabungan untuk perang, jadi ini kita gunakan untuk membeli barang. Jika barang ini murah, langsung kita beli banyak terutama barang fastmoving, jadi kita beli banyak, akan kita stock, karena kita yakin ini akan habis kurang dari satu bulan, dan harganya murah. Barang cepat laku, harga murah dan kita harus bayar kontan. Jadi kita mainnya di tabungan perang ini Pak. Yang kedua, adalah untuk pembesaran toko. Jadi biasanya kita ada barang-barang tertentu karena barang ini kan makin berubah, terutama distributor dari China itu, mereka itu semakin aneka macam barang semakin banyak. Semakin unik, semakin membuat orang itu permintaan itu semakin unik juga. Jadi tabungan ini kita gunakan untuk membeli barangbarang baru. Dan kita kalau beli barang baru, belum tentu barang baru ini bisa jalan atau tidak. Kita ada anggaran untuk ini juga. Dan yang ketiga, untuk privenya kita sendiri, untuk usaha keluarga, untuk kebutuhan keluarga. Jadi kita bagi tiga." (AL)

"Kalau menurut saya, tentunya dengan adanya kas dan jika kondisinya sesuai diharapkan pasti bisnis berkembang. Otomatis kalau bisnis berkembang, kasnya bertambah pak. Nah dengan kas bertambah ini, kalau menurut saya itu tidak 
harus terlalu banyak, misalnya sampai setahun kebutuhan tapi bisa kurang lebih tiga sampai empat bulan kebutuhan juga gapapa." (DRM)

Menurut narasumber AW ada 2 hal penting dalam pengelolaan kas yaitu: (1) kecukupan dana kas dalam operasional perusahaan; (2) kecukupan dana kas dalam investasi perusahaan. Narasumber AL mengungkapkan cara dalam mengelola uang kas di dalam tabungan yaitu: (1) tabungan untuk "perang" artinya kita gunakan untuk membeli secara langsung barang yang murah terutama barang fastmoving; (2) tabungan untuk pengembangan usaha yang kita gunakan untuk membeli barang-barang baru; (3) tabungan untuk kebutuhan sendiri dari perusahaan. Di sisi lain, menurut narasumber DRM bahwa uang kas dalam usaha tidak terlalu banyak, tetapi juga tidak terlalu sedikit, artinya perusahaan harus memiliki uang kas yang cukup untuk seluruh kebutuhan perusahaan.

\section{Manajemen Piutang Untuk Pengelolaan Modal Kerja}

Manajemen piutang untuk pengelolaan modal kerja menjadi hal yang penting, karena jika banyak piutang yang tidak tertagih akan menyulitkan perusahaan dalam melaksanakan kegiatan operasional perusahaan. Berikut narasumber RF, AL, dan AWP mengungkapkan berkaitan dengan manajemen piutang untuk pengelolaan modal kerja, sebagai berikut:

"Kalau piutang ya itu tadi kita harus disiplin sama customer-customer kita itu tadi. Harus tempo seberapa lama gitu. Berapa lama tempo yang dibayarkan gitu." (RF)

"Untuk piutangnya, yang kita atur term temponya yang kita atur itu berbeda-beda. Jadi terhadap customer kita, kita membe- rikan term waktu yang berbeda-beda. Jadi jika mereka mengambil itu ada batasnya, misalnya di bawah 5 juta kita berikan waktu berapa minggu aja mereka harus membayar. Tapi jika di atas 5 juta, ada berapa waktunya juga, di atas 10 juta juga ada waktunya." (AL)

"Untuk saat ini, lebih ketatkan lagi, salesnya harus terkontrol dan terpantau." (AWP)

Hal yang diungkapkan narasumber RF bahwa diperlukan adanya kedisiplinan terhadap konsumen berkaitan dengan pembayaran yang jatuh tempo. Di sisi lain, narasumber AL mendukung penyataan narasumber RF bahwa diperlukan pengaturan dari jatuh tempo pembayaran dan sekaligus dipertimbangkan adanya pemberian jangka waktu tempo yang berbeda bagi setiap konsumen yang bergantung pada jumlah pembelian yang dilakukan oleh konsumen. Selain itu, narasumber AWP menjelaskan bahwa diperlukan kontrol bagi sales yang ditugaskan agar tidak melakukan hal yang tidak benar sehingga dapat terpantau dengan baik. Narasumber AW dan DRM mengungkapkan dengan manajemen piutang terkait dengan pengelolaan modal kerja sebagai berikut:

"Disini kan ada aging ya pak. Untuk agingnya ini katakanlah kita kadang kurang bagus. Karena jujur kalau dia hutang, sudah umur berapa ini." (AW)

"Tapi kalau di industri distribusi, di mana umumnya kita memberikan piutang kepada client, di mana tentunya kita harus memberikan 2 hal, yaitu limit kredit dan tempo, di mana kita melihat kemampuan bayar dan karakter dari pihak yang bekerja sama dengan kita, terutama kalaupun mereka toko besar namun tidak punya etiket baik untuk membayar tepat waktu, tentunya kita harus memberikan tempo di mana dapat memberikan aturan yang jelas, berapa lama harus dibayar 
ataupun limit kredit. Jadi, fungsinya sebenarnya kita bukan menekan pada toko yang bekerja sama dengan kita namun untuk mengamankan diri kita sendiri, apalagi jika kita memiliki modal yang terbatas namun kita terlalu berambisi untuk menguasai pasar, itu tentunya akan ber-impact ke kita akhirnya kita apa, kita tidak punya cash untuk operasional dan kalaupun toko itu ternyata tidak bisa ditagih, maka berakibat pada keseluruhan bisnis kita." (DRM)

Pernyataan narasumber AW menunjukkan pentingnya aging dalam manajemen piutang. Aging atau aging schedule adalah sebuah laporan atau tabel dari semua akun piutang usaha yang berisi daftar debitur dengan nama, menunjukkan jumlah total yang terutang pada setiap debitur, dan menunjukkan berapa banyak jumlah yang harus dibayarkan oleh setiap debitur yang jatuh tempo dalam jangka waktu tertentu. Oleh karena itu, aging memberikan pengaruh besar dalam keberhasilan dari manajemen piutang perusahaan. Di sisi lain narasumber DRM menjelaskan bahwa pentingnya limit kredit dan tempo jangka waktu pembayaran. Hal ini dilakukan sebenarnya tidak untuk menekan pada konsumen yang bekerja sama dengan kita namun untuk mengamankan posisi kita dari piutang yang tidak tertagih.

\section{Manajemen Persediaan Untuk Pengelolaan Modal Kerja}

Manajemen persediaan untuk pengelolaan modal kerja menjadi penting karena barang yang terlalu lama di gudang sebab perputaran persediaan yang lambat akan menimbulkan biaya. Hal ini mendorong perusahaan agar perputaran persediaan dapat berjalan dengan baik, sehingga biaya persediaan menjadi rendah. Berikut ini meru- pakan pernyataan narasumber RF, AL, dan AWP berkaitan dengan manajemen persediaan yang dilakukan untuk pengelolaan modal kerja sebagai berikut:

"Untuk persediaan, jadi di perusahaan saya itu produksi per hari itu mesin aktif selama 8-10 jam. Jadi produksi untuk hari itu dibuat stock untuk besok." (RF)

"Kalau barang kebutuhan itu setengah aja sudah terambil dan kita harus pesan lagi. Kalau barang fastmoving, jika stock sisa tiga kita pesan lagi. Kalau barang yang lambat jalannya itu jika habis baru kita pesan. Ataupun kalau habis tapi tidak terlalu jalan kita tidak pesan lagi." (AL)

"Maka saya akan membeli bahan baku ketika sudah mau habis, langsung saya bikin, setengah jadi, besoknya sudah harus bisa jadi bahan jadi, langsung dipasarkan, kita juga hitung jangka waktu, misal 2 bulan, nah dekat-dekat itu saya sudah harus beli." (AWP)

Narasumber RF memperhitungkan produktivitas dari mesin yang digunakan agar dapat optimal dan dapat mempersiapkan persediaan untuk ke depan dengan memperhitungkan produksi yang dilakukan saat ini. Di sisi lain, narasumber AL menyatakan ada 3 jenis barang yang diklasifikasikan akan mempengaruhi proses dalam persediaan, antara lain: (1) barang kebutuhan; yaitu ketika jumlah barang ini setengah telah habis, maka harus dilakukan pemesanan lagi; (2) barang fastmoving, yaitu ketika jumlah barang ini yang tersisa tiga, maka harus dilakukan pemesanan lagi; (3) barang lambat; yaitu ketika jumlah barang ini telah habis maka akan dilakukan pemesanan kembali. Selanjutnya, narasumber AWP mengungkapkan bahwa pemesanan bahan baku akan dilakukan dengan kondisi ketika bahan baku akan habis dan ketika bahan baku 
sudah datang, maka langsung diolah menjadi bahan setengah jadi, sehingga bisa segera dijual. Selanjutnya, berikut pernyataan narasumber AW dan DRM tentang manajemen utang dalam pengelolaan modal kerja, yaitu:

"Tentunya untuk just in time, kami punya pengalaman deal beberapa kali dengan supplier yang bisa diandalkan dari harga, kualitas, dan waktu delivery sehingga mempersempit ruang gudang, bahkan bisa nol. Menghindari rusak, kehilangan, dan sebagainya." $(A W)$

"Pengelolaan persediaan di industri retail biasanya saya sesuaikan dengan kemampuan pengiriman supplier, jadi misalnya pengiriman supplier ketika order itu 1 hari, maka saya akan kasih spelling 2 hari atau lebih, kalau 1 minggu berarti sekitar 10 hari. Jadi contohnya misalnya kita melihat barang, kita harus mengetahui penjualan secara per periode. Misalnya kita secara persediaan ini kan berkaitan dengan gudang. Nah, gudang kita ini menampung berapa persen dari penjualan per bulan." (DRM)

Pernyataan narasumber AW menyebutkan bahwa pemesanan dilakukan dengan cara just in time, sehingga tidak menggunakan ruang gudang yang terlalu besar bahkan bisa tidak sama sekali menggunakan ruang gudang. Selain itu, dampak lainnya menghindari terjadinya kerusakan barang, kehilangan, dan sebagainya. Di sisi lain, narasumber DRM menjelaskan bahwa pemesanan persediaan yang dilakukan kepada supplier harus disesuaikan dengan beberapa hal penting yaitu: (1) kapasitas dari gudang yang kita miliki; (2) waktu pemesanan untuk persediaan kepada supplier.

\section{Strategi Dalam Pengelolaan Modal Kerja}

Strategi dalam pengelolaan modal kerja menjadi penting karena kas, piutang, persediaan memiliki peran yang signifikan dalam berjalannya operasional perusahaan. Penggunaan modal kerja yang efisien dan efektif akan membuat perusahaan memiliki kinerja keuangan yang baik. Berikut ini pernyataan narasumber RK, AL, dan AWP tentang strategi dalam pengelolaan modal kerja, yaitu:

"Biasanya dari awal ada transaksi gitu pak itu ada kontraknya dulu. Jadi kontrak berapa banyak produk yang dibutuhkan, lalu untuk sampai berapa bulan pembayarannya itu dilakukan." (RF)

"Yang saya gunakan yang pasti adalah harganya beda, jadi kita memberikan harga-harga beda untuk pembeli-pembeli yang kredit. Jadi tergantung dengan pembeliannya mereka dan juga prospeknya ke depan, dan juga seberapa besar usaha mereka." (AL)

"Strateginya kalau dari produk itu tadi pak, tidak terlalu stok banyak juga, kita juga harus evaluasi untuk penjualan perbulan itu berapa banyak, jadi kita bisa tau untuk menyediakan persediaan selama 1-2 bulan, di mana untuk produksi itu juga harus ada tanda perhitungannya, dasarnya dari apa kita bisa produksi segitu banyak, karena kita kan menjual produk yang dibatasi dengan waktu expired." (AWP)

"Strategi yang lain adalah untuk rutin mencari supplier yang harganya bisa lebih rendah tapi bisa di-nego system pembayaran dan minimum ordernya karena kita juga masih skala menengah, dan perputarannya kan juga belum banyak." (AWP)

Pernyataan narasumber RF menunjukkan bahwa strategi dalam pengelolaan modal kerja berkaitan dengan kebutuhan produk yang diha- 
silkan dan pembayaran yang dilakukan merupakan aktivitas dari modal kerja yang harus dilandasi kontrak yang jelas. Di sisi lain, AL mengungkapkan bahwa harga menjadi strategi dalam pengelolaan modal kerja dalam penjualan secara kredit dengan mempertimbangkan 2 hal yaitu: (1) prospek ke depan dari konsumen yang membeli; (2) besarnya usaha yang dimiliki konsumen. Narasumber AWP mengungkapkan bahwa strategi dalam pengelolaan modal kerja, antara lain: (1) evaluasi terhadap penjualan yang selama ini dilakukan karena akan mempengaruhi modal kerja; (2) perhitungan yang benar terhadap jumlah produksi yang dilakukan; (3) secara rutin mencari supplier dengan penawaran harga yang lebih rendah dan sistem pembayaran serta minimum pemesanan yang dapat diterima. Selanjutnya, narasumber AW dan DRM memberikan pernyataan, sebagai berikut:

"Kita berikan workshop yang justru terapan pengelolaan modal kerja." ( $A W)$

"Kalau strategi penggunaan modal kerja, tentunya modal kita ngga terlalu banyak, jadi kita kalaupun memiliki uang lebih itu bisa kita gunakan untuk membeli produkproduk yang jika dibeli dalam jumlah besar akan ada potongan harganya. Nah, kalaupun ngga ada potongan harga ya kita ga usah beli dalam jumlah besar. Kemudian yang kedua, kita juga harus pandai-pandai mengatur jenis-jenis supplier, karena supplier ini juga ada supplier tertentu yang mau memberikan secara kredit, tentunya kalau kita bisa dapat barang secara kredit itu akan menolong arus kas, kayak gitu sih." (DRM).

Berdasarkan pernyataan narasumber AW bahwa pelaku usaha perlu diberikan pelatihan untuk penerapan manajemen modal kerja. Di sisi lain, narasumber DRM mengungkapkan bahwa strategi dalam manajemen pengelolaan modal kerja yaitu: (1) ketika membeli barang perlu memperhatikan potongan harga; (2) penentuan supplier yang tepat khususnya berkaitan dengan jangka waktu pembayaran secara kredit.

\section{Kebijakan Dalam Pengelolaan Modal Kerja}

Kebijakan dalam pengelolaan modal kerja diperlukan agar dapat memaksimalkan kinerja usaha dari perusahaan. Kebijakan dalam modal kerja diharapkan dapat meningkatkan produktivitas dalam manajemen kas, piutang dan persediaan dari perusahaan. Berikut ini pernyataan narasumber RF, AL, dan AWP tentang kebijakan dalam pengelolaan modal kerja, yaitu:

"Kebijakannya ya itu tadi, dari tempo pembayaran, untuk kas ya itu balancing antara kas keluar dan kas masuk. Bagaimana kasnya itu tidak kekurangan dan tidak kelebihan." (RF)

"Yang pasti pertama adalah untuk customer-customer kita yang mau mengambil usaha kredit tidak kita beri kredit secara langsung. Minimum pembelian lima kali terlebih dahulu, dengan nominal tertentu yang kita tentukan. Jadi itu harus ditentukan dulu. Yang kedua yang tadi sudah sempat saya singgung, tanda terima dulu tapi ketika hari liburan panjang, jadi kita h-2 minggu kita sudah tidak menerima tanda terima ataupun pembayaran." $(A L)$

"Kalo saya ingin tetap memaksimalkan agar uang kas ini semaksimal untuk pengadaan bahan baku, kalo sekiranya lebih boleh lah untuk diinvestasikan." (AWP)

Pernyataan narasumber RF bahwa kebijakan dalam modal kerja yang perlu diperhatikan yaitu tempo pemba- 
yaran dari konsumen dan kepada pemasok, sehingga dapat mengatur kas masuk dan keluar dengan tepat dan kas tidak kekurangan dan kas tidak kelebihan. Di sisi lain, narasumber AL mengungkapkan bahwa kebijakan dalam modal kerja perlu memperhatikan persyaratan pembayaran dari konsumen yang diperbolehkan membeli dengan kredit yaitu: (1) minimum frekuensi pembelian; (2) nominal jumlah pembelian. Narasumber AWP mengungkapkan bahwa penting untuk memprioritaskan kas untuk kebutuhan pembelian bahan baku dan selanjutkan diperuntukkan bagi investasi. Selanjutnya, narasumber AW dan DRM memberikan pernyataan, sebagai berikut:

"Ya sekarang belum terintegrasinya kebijakan masing-masing....” (AW)

"Kalau kebijakan penggunaan modal sih untuk skala menengah mau ga mau kita sudah berhadapan dengan bank, nah kadang-kadang ada kredit, namun untuk mengoptimalisasi tanpa menaikkan risiko terlalu tinggi tentunya perlu batasanbatasan. Jadi kalaupun mereka mau ekspansi, harus disertai dengan perhitungan yang matang. Mereka mau kredit berapa lama, kemudian kira-kira kemampuan bayarnya seperti apa." (DRM)

Berdasarkan pernyataan narasumber AW bahwa pentingnya kebijakan dalam manajemen modal kerja yang dilakukan secara terintegrasi, sehingga dapat dilakukan pengambilan keputusan keuangan yang tepat. Selanjutnya narasumber DRM mengungkapkan 2 hal penting berkaitan dengan kebijakan dalam modal kerja yaitu: (1) ketika dilakukan ekspansi maka harus dilakukan perhitungan proyeksi yang benar; (2) ketika menggunakan kredit dari bank maka harus diperhitungkan kemampuan membayar.

\section{KESIMPULAN}

1. Pihak pengusaha skala menengah dapat memahami konsep modal kerja dengan benar yaitu dengan siklus konversi kas yang pendek, artinya mampu mengumpulkan piutang dengan cepat dan mengelola persediaan dengan tepat, serta membayar kepada pemasok lebih lambat namun dengan tetap menjaga kredibilitasnya.

2. Pihak pengusaha skala menengah dapat melaksanakan, mengevaluasi dan menindaklanjuti berkaitan dengan manajemen modal kerja, sehingga tidak ada kredit yang macet.

3. Pihak pengusaha skala menengah dapat melakukan manajemen modal kerja dengan mempertimbangkan risiko usaha dan kondisi ekonomi yang dapat mempengaruhi manajemen modal kerja.

\section{SARAN}

1. Pengusaha skala menengah perlu membuat kebijakan modal kerja yang terintegrasi, sehingga dapat melakukan pengambilan keputusan secara cepat dan tepat.

2. Pengusaha skala menengah perlu diberikan pelatihan untuk penerapan manajemen modal kerja.

\section{DAFTAR KEPUSTAKAAN}

Ahmad, Kamarudin, 1997, Dasardasar Manajemen Modal Kerja, Rineka Cipta, Jakarta.

Atmaja, Lukas Setia, 2001, Manajemen Keuangan, Andi, Yogyakarta.

Brealey, Richard A., Stewart C. Myers dan Alan J. Marcus, 2007, Dasardasar Manajemen Keuangan Perusahaan, Jilid 1, Erlangga, Jakarta. 
Brigham, Eugene F. dan Joel F. Houston, 2014, Dasar-dasar Manajemen Keuangan, Salemba Empat, Jakarta.

Bungin, M. Burhan, 2008, Penelitian Kualitatif: Komunikasi, Ekonomi, Kebijakan Publik, dan Ilmu Sosial Lainnya, Cetakan 2, Kencana, Jakarta.

Deloof, M., 2003, Does Working Capital Management Affects Profitability of Belgian Firms?, Journal of Business Finance and Accounting, Vol. 30, No. 3 \& 4.

Denzin, Norman K. dan Yvonna S. Lincoln, 2009, Hand Book of Qualitative Research, Translated by Dariyatno, Badrus Samsul Fata, Abi dan John Rinaldi, Pustaka Pelajar, Yogyakarta.

Horne, James C. Van dan John M. Wachowicz, 1997, Prinsip-prinsip Manajemen Keuangan, Salemba Empat, Jakarta.

Husnan, Suad, 1998, Manajemen Keuangan Teori dan Penerapan (Keputusan Jangka Pendek), Buku 2, BPFE, Yogyakarta.
Margono, S., 2010, Metodologi Penelitian Pendidikan, Rineka Cipta, Jakarta.

Miles, Matthew B., A. Michael Huberman dan Johnny Saldana, 2014, Analisis Data Kualitatif, Translated by Tjetjep Rohendi Rohidi, Universitas Indonesia Press, Jakarta.

Padachi, Kesseven, 2006, Trends in Working Capital Management and its Impact on Firms' Performance: An Analysis of Mauritian Small Manufacturing Firms, http://www.b izresearchpapers.com/Kesseven.pdf (diakses tanggal 07 Juni 2011).

Riyanto, Bambang, 1999, Dasar-dasar Pembelanjaan Perusahaan, BPFE, Yogyakarta.

Sugiyono, 2013, Metode Penelitian Kuantitatif Kualitatif dan $R \& D$, Alfabeta, Bandung.

Wild, John J., K. R. Subramanyan dan Robert F. Hasley, 2005, Financial Statement Analysis - Analisis Laporan Keuangan, Edisi 8, Buku Dua, Salemba Empat, Jakarta. 